\title{
Effect of processing conditions on chemical composition and consumer acceptability of cocoyam (colocasia esculentus) elubo
}

\section{Olayinka Ramota Karim, Samson Adeoye Oyeyinka, Ibukunoluwa Olawuyi, Olaide Akinwunmi Akintayo, Moses Olapade}

University of Ilorin, Ilorin, Nigeria

\section{Keywords: \\ Cocoyam \\ Taro \\ Elubo \\ Amala \\ Parboiling \\ Stepping}

\section{Article history:}

Received 18.11.2017

Received in revised

form 28.12.2017

Accepted 29.12.2017

Corresponding

author:

Olayinka Ramota Karim

E-mail:

olayinkakarim@

yahoo.com

DOI: $10.24263 / 2310-$

1008-2017-5-2-8

\section{Abstract}

Introduction. The effect of two processing conditions on chemical and consumer acceptability of cocoyam (taro) elubo was investigated.

Materials and methods: Fresh taro tubers were processed into elubo using traditional method of four treatments $\left(\mathrm{P}_{50} \mathrm{~S}_{12}\right.$; $\mathrm{P}_{50} \mathrm{~S}_{24 ;} \mathrm{P}_{60} \mathrm{~S}_{12}$ and $\mathrm{P}_{60} \mathrm{~S}_{24}$ ) from parboiling at $50^{\circ} \mathrm{C}$ for $3 \mathrm{~h}$ and at $60^{\circ} \mathrm{C}$ for $1 \mathrm{~h}$; steeping in water for $12 \mathrm{~h}$ and $24 \mathrm{~h}$. Standard methods were used to determine the proximate and mineral composition of the elubo samples. A stiff gel (amala) was prepared from the elubo samples to evaluate the sensory quality and consumer acceptability.

Results and discussion: The proximate composition of the taro elubo samples revealed that the processing treatments had no significant $(\mathrm{p}<0.05)$ effect on the crude fibre $(3.80$ to $3.83 \%)$, carbohydrate $(77.50$ to $78.80 \%)$, and calories $(345.32$ to $349.47 \mathrm{~K})$, while, significant $(\mathrm{p}<0.05)$ effects were observed on the moisture $(8.39$ to $9.30 \%)$, ash $(1.56$ to $2.98 \%)$ and protein $\left(5.08\right.$ to $6.26 \%$ ) contents. Parboiling at $50^{\circ} \mathrm{C}$ resulted in lower moisture content, though all the values are still within the acceptable level for storage of food flour. The ash content of the taro elubo was significantly $(\mathrm{p}<0.05)$ influenced by steeping at $12 \mathrm{~h}$ with elubo sample obtained from $\mathrm{P}_{60} \mathrm{~S}_{12}$ treatment having the highest value. Stepping at $12 \mathrm{~h}$ also favoured the protein content, the $\mathrm{P}_{50} \mathrm{~S}_{12}$ recorded the highest value. The usual lost of minerals through heat treatment (parboiling) and leaching (stepping) was observed as the fresh taro had significantly $(\mathrm{p}<0.05)$ high mineral composition. Elubo sample obtained from $\mathrm{P}_{50} \mathrm{~S}_{12}$ and $\mathrm{P}_{60} \mathrm{~S}_{12}$ treatments the highest value for calcium $(30.87 \mathrm{mg} / 100 \mathrm{~g})$ and potassium $(47.00 \mathrm{mg} / \mathrm{g})$ respectively. Increase in steeping time caused a significant $(\mathrm{p}<0.05)$ reduction in the values obtained for calcium, potassium and sodium. There was no significant $(p<0.05)$ effect on the iron and manganese contents of the elubo samples. The sensory qualities of the amala samples showed that parboiling of taro at $50^{\circ} \mathrm{C}$ resulted in amala having no significant $(\mathrm{p}<0.0)$ difference in colour, taste, aroma, consistency and general acceptability with yam amala (the reference sample). This indicates that low heat treatment is required for processing of taro corms.

Conclusions. The study showed that the parboiling at $50^{\circ} \mathrm{C}$ and stepping at $12 \mathrm{~h}$ favoured the chemical and sensory qualities and consumer acceptability of taro elubo than parboiling at $60^{\circ} \mathrm{C}$ and stepping at $24 \mathrm{~h}$. 


\section{Introduction}

Cocoyam commonly called taro is an underutilized crop mainly grown for its edible corms. Taro (Colocasia esculenta) and Tannia (Xanthosoma sagittifolium) are the two most important genera of the family Aracea [40, 14, 2]. They constitute one of the six most important root and tuber crops worldwide [13]. Although, they are less important than other tropical root crops such as yam, cassava and sweet potato, they are still a major staple in some parts of the tropics and sub-tropics [38]. Taro is produced in abundance in Nigeria, but less valued as it is regarded as staple food for rural dwellers, the poor and the less privileged in society [20,34]. The nutritional and chemical composition as reported by FAO [15] shows that cocoyam if fully exploited would enhance the food security of people living in the tropics [14].

Corms of taro have generally been reported to contain digestible starch which is an important factor when selecting a starchy food that will not be cumbersome on the digestive system [19] protein of good quality, ascorbic acid, thiamin, riboflavin, niacin and high scores of amino acids [32]. Report shows that $70-80 \%$ starch content is with small size granules [37, 8, 34], which result in high digestibility. According to [22] starch derived from taro corm is unique because of its very small granular size ranging from 1-5 $\mu$, significantly smaller than that of corn and wheat. The protein and amino acids content are also higher than other tropical root crops $[24,7]$. It is also rich in dietary fibre, thiamine, calcium, niacin, manganese, magnesium, copper and riboflavin. Consuming nutrientspacked food like taro is vital for maintaining a healthy immune system, which helps our body to make use of protein, carbohydrates and other nutrients in the food [36].

Processing greatly increase the utilization of root crops and reduces annual postharvest loss of about 30\% [23]. Cocoyam flour (elubo) like yam elubo is a major form in which the tuber could be preserved and consumed during the periods preceding yam harvest and this underscores its importance as a possible substitute for yam in Nigeria $[1,18,4]$. The processing method however affects final product quality [29, 30, 32].

In the traditional production of elubo, the major processing units of critical control include; parboiling, steeping, and drying [31, 11,30]. Parboiling and steeping improve the digestibility, promote palatability, improve keeping quality, reduces anti-nutritional factors and have effect on the major nutrients, including proteins, carbohydrates, minerals and vitamins $[29,28,30,32]$, hence appropriate processing conditions are required to ascertain quality of the final product. The study was designed to determine the effect of parboiling and steeping conditions on for proximate, minerals and acceptability of taro elubo.

\section{Materials and methods}

The cocoyam corms were obtained from the local food market in Osogbo, Osun State, Nigeria.

\section{Production of cocoyam elubo}

The method reported by [29] was adopted for production of the cocoyam elubo. Clean cocoyam corms were sorted from infected tubers. The selected tubers were peeled and reduced into even chips $(150 \pm 3 \mathrm{~g})$. The chips were divided into for parboiling at $50^{\circ} \mathrm{C}$ for $3 \mathrm{~h}$ and at $60^{\circ} \mathrm{C}$ for $1 \mathrm{~h}$, steeped in the warm water for $12 \mathrm{~h}$ and $24 \mathrm{~h}$ resulting into four treatments. The parboiled chips were later sun-dried till a constant weight was obtained. 
The dried chips were milled into flour (elubo) using attrition mill and sieved with $0.25 \mathrm{um}$ sieve. The elubo samples were packaged in high density polyethylene bags $(10 \mathrm{~mm}$ thickness) for further analysis.

\section{Proximate Analysis}

Proximate composition of the taro elubo samples were determined using the method described by AOAC [9]. Moisture, ash, crude fat, protein and crude fibre were determined, while carbohydrate content was determined using difference method.

\section{Mineral Analysis}

The mineral content of the elubo was determined using the method described by [27]. Elubo sample of $0.5 \mathrm{~g}$ was weighed into a clean ceramic crucible. A blank was prepared with empty crucible. The crucible was placed in a muffle furnace at $50^{\circ} \mathrm{C}$ for $4 \mathrm{~h}$. The sample was allowed to cool down in the oven after which it was removed carefully. The ashed sample was poured into already labeled $50 \mathrm{ml}$ centrifuge tube. The crucible was rinsed with $5 \mathrm{ml}$ of distilled water into the centrifuge tube. The crucible was rinsed again with $5 \mathrm{ml}$ of aqua regia. This was repeated to make a total volume of $20 \mathrm{ml}$. The sample was mixed properly and centrifuged (ICE Centra GP8) for 10 minutes. The supernatant was decanted into clean vials for mineral determination. The absorbance was read on atomic absorption spectrophotometer (Buck Scientific Model 200A) at different wavelength for each mineral element (copper $-324.8 \mathrm{~nm}$, zinc $-213.9 \mathrm{~nm}$, calcium $-422.7 \mathrm{~nm}$, iron $-248.3 \mathrm{~nm}$, magnesium-285.2nm, manganese $-279.5 \mathrm{~nm}$, sodium $-589 \mathrm{~nm}$ and potassium $-766.5 \mathrm{~nm}$ ).

\section{Preparation of amala}

The procedure described by [10] was adopted for the preparation of taro amala. About $50 \mathrm{~g}$ taro amala was added to $200 \mathrm{ml}$ boiled water. The paste was stirred manually with a wooden spoon over a low flame until a smooth consistency was obtained.

\section{Sensory evaluation and consumer acceptability test}

The sensory quality [1] and consumer acceptability of taro amala was evaluated using 50 panelists that were familiar with yam amala. A nine point hedonic scale as described by $[21,19]$ was adopted. The scale ranged from like extremely (9) to dislike extremely (1). Each of the samples was rated for appearance, aroma, taste, texture, mouth feel and overall acceptability

\section{Statistical analysis}

Data were subjected to multiple analyses of variance (MANOVA) at $5 \%$ significance level, and mean of samples separated by Duncan multiple range test (DMRT) using statistical package for social sciences (SPSS) version 20.0. 


\section{Results and Discussion}

\section{Proximate composition of taro elubo}

The result of proximate composition of fresh taro and taro elubo is presented in Table 1. The two varied processing units (parboiling and steeping) were observed to have significant $(\mathrm{p}<0.05)$ effect on the taro elubo samples. Fresh taro corms constitute majorly of moisture with other macronutrients in low concentration [34]. The apparent increase in protein, fat, crude fibre and carbohydrate contents observed in taro elubo samples could be as a result of the removal of moisture and processing conditions which tend to increase the concentration of nutrients [26].

The moisture content ranging from 8.39 to $9.30 \%$ was significantly $(\mathrm{p}<0.05)$ affected by the processing conditions. Elubo from $\mathrm{P}_{50} \mathrm{~S}_{24}$ treatment had the lowest moisture content, while the highest value was observed in elubo from $\mathrm{P}_{60} \mathrm{~S}_{12}$ treatment. The results revealed that parboiling at $50^{\circ} \mathrm{C}$ and steeping for $24 \mathrm{~h}$ resulted into lower moisture content compared to parboiling at $60^{\circ} \mathrm{C}$ and steeping for $24 \mathrm{~h}$. This could be as a result of more dissociation of the starch granules, easing heat transfer and surface evaporation of moisture. Moisture content of food or processed products give an indication of its anticipated shelf life. High moisture content enhances microbial contamination and reduces food quality and stability [5], therefore the lower the moisture content of a sample, the more its storability. The values are lower than the values $(9.43-10.47 \%)$ reported for cocoyam flour by [31], however the values fall within the acceptable limit of not more than $10 \%$ for long term storage of flour $[33,12]$.

The fresh corm had the significantly $(\mathrm{p}<0.05)$ highest ash content, which indicates that taro in their fresh state is rich in minerals [7, 14]. The effect of parboiling and steeping conditions is thus significant $(\mathrm{p}<0.05)$ on the ash contents of the elubo samples. Parboiling and steeping conditions have been reported to reduce ash content of processed food products $[6,11]$. The ash contents of the taro elubo are higher than the value reported for yam elubo (1.84\%) by [25] and [11]. While, the range of 1.56 to $2.98 \%$ reported by [39] for cocoyam flour is similar to the values obtained from the study. The result indicates that the taro elubo could be a good source of essential minerals and trace elements.

The protein content of root and tuber crops is generally low. Processing of taro into elubo influenced the protein content due to concentration of the nutrient upon drying. The highest value $(6.45 \%)$ was obtained from elubo from $\mathrm{P}_{50} \mathrm{~S}_{24}$, treatment, while elubo from $\mathrm{P}_{60} \mathrm{~S}_{12}$ had the lowest value $(5.06 \%)$. The variation in protein content consequently was due to the effect of the processing conditions. Heat application denatures proteins [26, 19, 24]. At higher parboiling temperature $\left(60^{\circ} \mathrm{C}\right)$, lower protein content was obtained, which may be as a result of heat denaturation of protein. Parboiling has been found to decrease protein content due to leaching of nitrogenous substances during steeping and rupturing of molecules during steaming [35] and this might be the reason for the observed effect. Also decrease in protein content probably occurred as a result of Maillard reaction, which occurs between carbohydrates and protein [2, 41]. Browning of elubo is responsible for the characteristic colour of the cooked paste (amala). The result is similar with the values reported by [29] and greater than the values reported by [3, 1, 28] for yam elubo. This explains that taro has higher protein content (thermo-stable) than yam.

There was no significant difference $(\mathrm{p}<0.05)$ between the fat contents of the taro elubo samples. Fat content in flour explains storability of the flour due to various chemical reactions associated with lipid oxidation [38]. Fat also serve as energy store in the body 
when is broken down to release glycerol thereafter converted into glucose (energy) by the liver. It has been reported that $1 \mathrm{~g}$ of fat provides $37 \mathrm{Kcal}$ of energy [16]. The low fat content of taro elubo may make it suitable for diabetics and people suffering from cardiovascular diseases.

The crude fibre content is similar to the ash content. The effect of the processing conditions were not significant $(\mathrm{p}<0.05)$ on the fibre content. These values compared well with values reported for cocoyam flour by [28, 29, 18]. Crude fibre represents the content of the non-digestible components of food, such as lignin, cellulose and hemicelluloses. These are essential in human nutrition, since they enhance the transit time through the bowels, facilitates bowels movement thus reducing the risk of colon cancer. The results indicate that taro elubo is rich in insoluble dietary fibre. This may be relevant in African's food and nutritional security. The high carbohydrate content of fresh taro was reflected on the values obtained from the elubo samples ( 77.50 to $78.80 \%)$. There was no significant $(\mathrm{p}<0.05)$ effect of the processing conditions on the carbohydrate content. However, the values are slightly higher than values obtained for yam flour from the study reported by [2] and cocoyam flour by [29]. Carbohydrate supplies energy to the body, contributes to fat metabolism, spares proteins as an energy source, act as a mild natural laxative for human beings and generally add to the bulk of the diet [16].

All the calorie contents of all the taro elubo samples are higher and significantly $(\mathrm{p}<0.05)$ different from the value of the fresh corm. The elubo from $\mathrm{P}_{50} \mathrm{~S}_{24}$ treatment had the highest calorific value. The result revealed that taro elubo though is a good source of carbohydrate, can be consumed in large amount without a substantial increase in the glycemic load in the body.

\section{Mineral composition of fresh taro and taro elubo}

The ranges of the mineral composition of taro elubo were: calcium (23.28 to 53.64 $\mathrm{mg} / 100 \mathrm{~g}$ ), potassium (21.45 to $79.53 \mathrm{mg} / 100 \mathrm{~g}$ ), sodium (15.33 to $65.22 \mathrm{mg} / 100 \mathrm{~g}$ ), magnesium ( 8.38 to $26.2 \mathrm{mg} / 100 \mathrm{~g}$ ), phosphorus ( 0.43 to $1.31 \mathrm{mg} / 100 \mathrm{~g})$, iron ( 0.22 to 1.53 $\mathrm{mg} / 100 \mathrm{~g})$, zinc $(0.10$ to $1.32 \mathrm{mg} / \mathrm{kg})$, and manganese $(1.10$ to $3.48 \mathrm{mg} / 100 \mathrm{~g})$ as shown in Table 2 . The nutritional potential, health and food security benefits of taro are justified with the rich essential mineral content [41].The variation in the mineral composition might have been influenced by the processing conditions as higher values were obtained for the fresh taro corm. Minerals are usually lost through heat treatment and leaching during parboiling and stepping, most especially with potassium, calcium and magnesium $[41,18]$. The processing methods had significant effect on potassium, calcium, sodium, magnesium and phosphorus, while no effect was obtained for iron and manganese contents. According to Hassan et al., [17] during processing the nutritive value and antinutritional components of roots and tubers may be adversely affected. Calcium is important in the body as it helps to build and maintain bones and teeth [41].

Sodium and potassium are water soluble and are sensitive to high heat processing. Increase in steeping time caused a significant reduction in the values obtained for potassium and sodium. Also, elubo samples obtained from steeping of taro for $12 \mathrm{~h}$ showed better values for potassium and sodium. Elubo sample from $\mathrm{P}_{60} \mathrm{~S}_{12}$ treatment had the highest sodium content while elubo sample from $\mathrm{P}_{50} \mathrm{~S}_{24}$ treatment had the lowest value. Potassium and sodium are important in the diet as they help to regulate acid-base equilibrium and osmotic pressure of body fluid. 
The values obtained for magnesium, phosphorus, iron, zinc and manganese are lower than the values reported by Hassan et al. [17].

Proximate composition of Fresh taro and taro elubo

Table 1

\begin{tabular}{|c|c|c|c|c|c|c|c|}
\hline$\frac{0}{\bar{a}}$ & 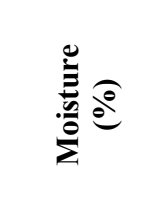 & $\frac{5}{4} \frac{\partial}{\partial}$ & 氖 & 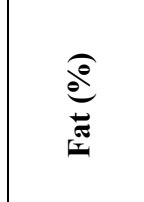 & 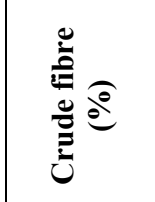 & 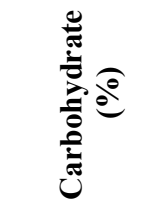 &  \\
\hline $\begin{array}{l}\text { Fresh } \\
\text { Taro }\end{array}$ & $48.93^{\mathrm{a}} \pm 0.42$ & $5.17^{\mathrm{a}} \pm 0.27$ & $2.08^{c} \pm 0.22$ & $0.63^{\mathrm{a}} \pm 0.01$ & $2.30^{\mathrm{b}} \pm 0.17$ & $40.90^{\mathrm{b}} \pm 0.53$ & $177.54^{\mathrm{b}} \pm 1.34$ \\
\hline $\mathrm{P}_{50} \mathrm{~S}_{12}$ & $8.82^{\mathrm{b}} \pm 0.74$ & $1.98^{\mathrm{bc}} \pm 0.14$ & $6.26^{\mathrm{b}} \pm 0.44$ & $1.34^{\mathrm{a}} \pm 0.32$ & $3.83^{\mathrm{a}} \pm 0.00$ & $77.77^{\mathrm{a}} \pm 1.20$ & $348.78^{a} \pm 3.72$ \\
\hline $\mathrm{P}_{50} \mathrm{~S}_{24}$ & $7.95^{\mathrm{b}} \pm 0.90$ & $1.70^{\mathrm{c}} \pm 0.07$ & $6.45^{\mathrm{a}} \pm 0.51$ & $1.28^{\mathrm{a}} \pm 0.77$ & $3.81^{\mathrm{a}} \pm 0.00$ & $78.81^{\mathrm{a}} \pm 1.24$ & $352.52^{\mathrm{a}} \pm 0.06$ \\
\hline $\mathrm{P}_{60} \mathrm{~S}_{12}$ & $9.30^{\mathrm{b}} \pm 0.37$ & $2.20^{\mathrm{b}} \pm 0.07$ & $5.86^{\mathrm{b}} \pm 0.80$ & $1.32^{\mathrm{a}} \pm 0.47$ & $3.82^{\mathrm{a}} \pm 0.04$ & $77.50^{\mathrm{a}} \pm 1.52$ & $345.32^{\mathrm{a}} \pm 1.33$ \\
\hline $\mathrm{P}_{60} \mathrm{~S}_{24}$ & $8.39^{\mathrm{b}} \pm 1.02$ & $1.82^{b c} \pm 0.58$ & $5.08^{\mathrm{c}} \pm 0.77$ & $1.23^{\mathrm{a}} \pm 0.64$ & $3.80^{\mathrm{a}} \pm 0.00$ & $79.68^{\mathrm{a}} \pm 2.29$ & $349.47^{\mathrm{a}} \pm 0.31$ \\
\hline
\end{tabular}

Mean values with different superscripts within the same column are significantly different at $\mathrm{p}<0.05$

$\mathrm{P}_{50} \mathrm{~S}_{12 \text { : }}$ parboiled at $50^{\circ} \mathrm{C}$, steeped for $12 \mathrm{~h}$

$\mathrm{P}_{50} \mathrm{~S}_{24}$ : parboiled at $50^{\circ} \mathrm{C}$, steeped for $24 \mathrm{~h}$

$\mathrm{P}_{60} \mathrm{~S}_{12}$ : parboiled at $60^{\circ} \mathrm{C}$, steeped for $12 \mathrm{~h}$

$\mathrm{P}_{60} \mathrm{~S}_{24}$ : parboiled at $60^{\circ} \mathrm{C}$, steeped for $24 \mathrm{~h}$

Table 2

\section{Minerals composition of fresh taro and taro elubo}

\begin{tabular}{|c|c|c|c|c|c|c|c|c|}
\hline$\frac{\tilde{e}}{\bar{E}}$ & 五 & 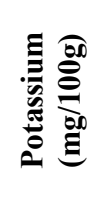 & 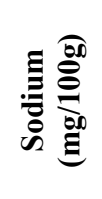 & 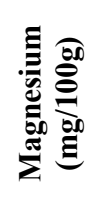 & 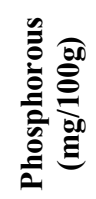 &  & 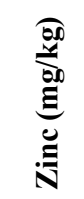 & 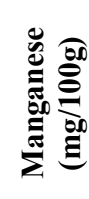 \\
\hline Fresh & $\begin{array}{l}53.64^{\mathrm{a}} \\
\pm 1.03\end{array}$ & $\begin{array}{l}79.53^{\mathrm{a}} \\
\pm 0.96\end{array}$ & $\begin{array}{l}65.22^{\mathrm{a}} \\
\pm 0.40\end{array}$ & $\begin{array}{c}26.2^{\mathrm{a}} \\
\pm 0.53\end{array}$ & $\begin{array}{c}2.03^{\mathrm{a}} \\
\pm 0.10\end{array}$ & $\begin{array}{r}1.53^{\mathrm{a}} \\
\pm 0.05 \\
\end{array}$ & $\begin{array}{r}1.32^{\mathrm{a}} \\
\pm 0.03 \\
\end{array}$ & $\begin{array}{c}3.48^{\mathrm{a}} \\
\pm 0.78\end{array}$ \\
\hline $\mathrm{P}_{50} \mathrm{~S}_{12}$ & $\begin{array}{l}30.87^{b} \\
\pm 0.72\end{array}$ & $\begin{array}{c}26.33^{\mathrm{cl}} \\
\pm 1.14 \\
\end{array}$ & $\begin{array}{l}23.15^{\mathrm{c}} \\
\pm 1.15 \\
\end{array}$ & $\begin{array}{l}8.67^{b c} \\
\pm 0.16 \\
\end{array}$ & $\begin{array}{c}0.88^{\mathrm{c}} \\
\pm 0.18 \\
\end{array}$ & $\begin{array}{r}0.22^{b} \\
\pm 0.04 \\
\end{array}$ & $\begin{array}{l}0.15^{\mathrm{b}} \\
\pm 0.01 \\
\end{array}$ & $\begin{array}{r}1.15^{\mathrm{b}} \\
\pm 0.18 \\
\end{array}$ \\
\hline $\mathrm{P}_{50} \mathrm{~S}_{24}$ & $\begin{array}{c}25.30^{\mathrm{cd}} \\
\pm 0.11\end{array}$ & $\begin{array}{l}21.45^{\mathrm{C}} \\
\pm 1.76\end{array}$ & $\begin{array}{c}15.33^{\mathrm{d}} \\
\pm 1.15\end{array}$ & $\begin{array}{c}8.38^{\mathrm{c}} \\
\pm 0.07\end{array}$ & $\begin{array}{c}0.92^{\mathrm{b}} \\
\pm 0.48\end{array}$ & $\begin{array}{l}0.42^{b} \\
\pm 0.29\end{array}$ & $\begin{array}{l}0.15^{b} \\
\pm 0.01\end{array}$ & $\begin{array}{l}1.15^{b} \\
\pm 0.00\end{array}$ \\
\hline $\mathrm{P}_{60} \mathrm{~S}_{12}$ & $\begin{array}{c}26.31^{\mathrm{bc}} \\
\pm 1.16\end{array}$ & $\begin{array}{l}47.00^{\mathrm{b}} \\
\pm 2.86\end{array}$ & $\begin{array}{c}31.63^{b} \\
\pm 1.38\end{array}$ & $\begin{array}{c}8.72^{\mathrm{b}} \\
\pm 0.26\end{array}$ & $\begin{array}{c}0.43^{\mathrm{d}} \\
\pm 0.25\end{array}$ & $\begin{array}{c}0.44^{b} \\
\pm 0.07\end{array}$ & $\begin{array}{c}0.10^{\mathrm{c}} \\
\pm 0.03\end{array}$ & $\begin{array}{c}1.10^{b} \\
\pm 0.02\end{array}$ \\
\hline $\mathrm{P}_{60} \mathrm{~S}_{24}$ & $\begin{array}{c}23.28^{\mathrm{d}} \\
\pm 0.10\end{array}$ & $\begin{array}{l}27.79^{\mathrm{c}} \\
\pm 1.58\end{array}$ & $\begin{array}{c}18.59^{\text {cd }} \\
\pm 1.38\end{array}$ & $\begin{array}{l}8.56^{\mathrm{bc}} \\
\pm 0.12\end{array}$ & $\begin{array}{l}0.57^{\text {cd }} \\
\pm 0.27\end{array}$ & $\begin{array}{l}0.51^{b} \\
\pm 0.02\end{array}$ & $\begin{array}{c}0.12^{\mathrm{c}} \\
\pm 0.00\end{array}$ & $\begin{array}{r}1.23^{b} \\
\pm 0.13\end{array}$ \\
\hline
\end{tabular}

Mean values with different superscripts within the same column are significantly different at $\mathrm{p}<0.05$

$\mathrm{P}_{50} \mathrm{~S}_{12 \text { : }}$ parboiled at $50^{\circ} \mathrm{C}$, steeped for $12 \mathrm{~h}$

$\mathrm{P}_{50} \mathrm{~S}_{24}$ : parboiled at $50^{\circ} \mathrm{C}$, steeped for $24 \mathrm{~h}$

$\mathrm{P}_{60} \mathrm{~S}_{12}$ : parboiled at $60^{\circ} \mathrm{C}$, steeped for $12 \mathrm{~h}$

$\mathrm{P}_{60} \mathrm{~S}_{24}$ : parboiled at $60^{\circ} \mathrm{C}$, steeped for $24 \mathrm{~h}$ 


\section{Sensory properties of taro amala}

The mean sensory scores of amala produced from the taro elubo samples varied significantly $(\mathrm{p}<0.05)$ as shown in Table 3 . The amala prepared from sample $\mathrm{P}_{50} \mathrm{~S}_{24}$ treatment had the highest mean score of 7.70 for colour and was more preferred than the reference sample (amala from yam elubo). The aroma values ranged from 7.55 to 6.20 with amala prepared from elubo of $\mathrm{P}_{50} \mathrm{~S}_{12}$ treatment having the highest score and amala from $\mathrm{P}_{60} \mathrm{~S}_{24}$ treatment having the least score. The reference recorded 7.05 for taste which were lower than some scores obtained for the taro amala samples. This indicates that on the average level, the taro amala samples had better scores than the yam amala. Parboiling of taro at $50^{\circ} \mathrm{C}$ influenced the consistency quality and mouth feel qualities. Consistency of amala explains the firmness and viscosity quality. This is one of the major acceptable characteristics of the stiff dough $[3,1,23]$. In generally, yam amala was most accepted than the taro amala samples. However, the amala obtained from taro elubo parboiled at $50^{\circ} \mathrm{C}$ were not significantly different from the reference. This indicates that low heat treatment is required for processing of taro corms.

Table 3

Sensory Quality and Consumer Acceptability scores of taro amala

\begin{tabular}{|l|c|c|c|c|c|c|}
\hline Samples & Colour & Taste & Aroma & $\begin{array}{c}\text { Mouth } \\
\text { feel }\end{array}$ & Consistency & $\begin{array}{c}\text { General } \\
\text { Acceptability }\end{array}$ \\
\hline Reference & $7.65^{\mathrm{a}} \pm 1.18$ & $\begin{array}{c}6.89^{\mathrm{b}} \pm \\
1.73\end{array}$ & $\begin{array}{c}7.05^{\mathrm{cd}} \pm \\
1.42\end{array}$ & $\begin{array}{c}7.40^{\mathrm{a}} \pm \\
1.79\end{array}$ & $7.0^{\mathrm{b}} \pm 1.45$ & $7.71^{\mathrm{a}} \pm 1.14$ \\
\hline $\mathrm{P}_{50} \mathrm{~S}_{12}$ & $7.67^{\mathrm{a}} \pm 1.40$ & $\begin{array}{c}6.97^{\mathrm{ab}} \\
\pm 1.69\end{array}$ & $\begin{array}{c}7.55^{\mathrm{a}} \pm \\
1.74\end{array}$ & $\begin{array}{c}7.05^{\mathrm{b}} \pm \\
1.62\end{array}$ & $7.08^{\mathrm{ab}} \pm 1.84$ & $7.67^{\mathrm{a}} \pm 1.56$ \\
\hline $\mathrm{P}_{50} \mathrm{~S}_{24}$ & $7.70^{\mathrm{a}}$ & $\begin{array}{c}7.00^{\mathrm{a}} \pm \\
\pm 1.56\end{array}$ & $\begin{array}{c}7.15^{\mathrm{c}} \pm \\
0.99\end{array}$ & $\begin{array}{c}7.15^{\mathrm{ab}} \pm \\
1.04\end{array}$ & $7.15^{\mathrm{a}} \pm 0.93$ & $7.60^{\mathrm{a}} \pm 0.73$ \\
\hline $\mathrm{P}_{60} \mathrm{~S}_{12}$ & $7.15^{\mathrm{b}} \pm 1.46$ & $\begin{array}{c}6.65^{\mathrm{c}} \pm \\
1.76\end{array}$ & $\begin{array}{c}7.30^{\mathrm{b}} \pm \\
1.87\end{array}$ & $\begin{array}{c}6.65^{\mathrm{c}} \pm \\
1.47\end{array}$ & $6.13^{\mathrm{e}} \pm 1.80$ & $6.85^{\mathrm{b}} \pm 1.69$ \\
\hline $\mathrm{P}_{60} \mathrm{~S}_{24}$ & $\begin{array}{c}6.25^{\mathrm{c}} \\
\pm 1.21\end{array}$ & $\begin{array}{c}6.05^{\mathrm{cd}} \\
\pm 1.54\end{array}$ & $\begin{array}{c}6.20^{\mathrm{f}} \pm \\
1.47\end{array}$ & $\begin{array}{c}6.95^{\mathrm{bc}} \pm \\
1.40\end{array}$ & $6.38^{\mathrm{d}} \pm 1.46$ & $6.70^{\mathrm{d}} \pm 1.38$ \\
\hline
\end{tabular}

Mean values with different superscripts within the same column are significantly different at $p<0.05$ Reference: Amala prepared from yam elubo

$\mathrm{P}_{50} \mathrm{~S}_{12}$ : Amala prepared from taro elubo parboiled at $50^{\circ} \mathrm{C}$ and steeped for $12 \mathrm{~h}$

$\mathrm{P}_{50} \mathrm{~S}_{24}$ : Amala prepared from taro elubo parboiled at $50^{\circ} \mathrm{C}$ and steeped for $24 \mathrm{~h}$

$\mathrm{P}_{60} \mathrm{~S}_{12}$ : Amala prepared from taro elubo parboiled at $60^{\circ} \mathrm{C}$ and steeped for $12 \mathrm{~h}$

$\mathrm{P}_{60} \mathrm{~S}_{24}$ : Amala prepared from taro elubo parboiled at $60^{\circ} \mathrm{C}$ and steeped for $24 \mathrm{~h}$

\section{Conclusion}

The study has shown that the chemical qualities of taro elubo are significantly influenced by the processing conditions. Parboiling at $50^{\circ} \mathrm{C}$ and stepping at $12 \mathrm{~h}$ favoured the chemical qualities than parboiling at $60^{\circ} \mathrm{C}$ and stepping at $24 \mathrm{~h}$. Amala from elubo produced from parboiling at $50^{\circ} \mathrm{C}$ and stepping at $12 \mathrm{~h}$ was also found to have similar sensory qualities and consumer acceptability with yam amala. 


\section{References}

1. Abulude I. O., Ojedara V.O. (2006), Development and quality evaluation of fortified 'amala', Acta Science Polonorum Tech Aliment, 5(2), pp. 127-134.

2. Adejumo I. O., Bamidele O. (2012), Cost implication of differently processed wild cocoyam Colocasia esculenta as feed ingredient broiler finishers, Journal of Science and Information Technology, pp. 1, pp. 7.

3. Adejumo I. O.N., Okundare, R.O., Afolayan O. I. Balogun S.A. (2013), Quality attributes of yam flour (elubo) as affected by blanching water temperature and soaking time. International Journal of Engineering Science, 2(1), pp. 216-221.

4. Ajibola S. O., Ajala I., Saka J. O. (2003), Efficiency of resource use among cocoyam farmers in Owo local government area in Ondo state, Nigeria, Journal of Agricultural Research, 4, pp. 281-287.

5. Akanbi T. O. Nazamid S. Adebowale A. A. (2009), Functional and pasting properties of a tropical breadfruit Artocarpusaltilis starch from Ile-Ife, Osun State. Nigeria, International Food Research Journal, 16, pp. 151-157.

6. Akissoe N., Hounbotigan D. J., Brieas., N., Vervier P., Nago, C. M. Olorunda A. (2001) Physical, chemical and sensory evaluation of dried yam flour and amala (a flour derived product), Tropical Science, 41, pp. 151-155.

7. Akunor, P. T., Tortoe C. Buckman, E. S. (2017), Evaluation of cocoyam -wheat composite flour in pastry products based on proximate composition, physicochemical, functional and sensory properties, Journal of Culinary Science and Technology, pp. 1-14.

8. Ammar M.S., Hegazy A.E., Bedeir S.H. (2009), Using of taro flour as partial substitute of wheat flour in bread making, World Journal of Dairy and Food Science, 4(2), pp. 9 - 99 .

9. AOAC. (2010), Official methods of Analysis. Association of Official Analytical Chemist AOAC, Washington, D.C., USA.

10. Awoyale A., Maziya-Dixon B., Sanni L.O. Shittu T. A. (2010), Nutritional and sensory properties of amala supplemented with distiller's spent grain (DSG), Journal of Food, Agriculture and Environment, 8, pp. 3, 4, 66-70

11. Babajide J. M., Oyewole O. B., Henshaw F. O., Babajide S.O., Olasatan F.O. (2006), Effect of local preservatives on the quality of traditional dry yam slices gbodo and its product. World Journal of Agricultural Science, 23, pp. 267-273.

12. Butt M.S., Nasir M., Akhtar S., Sharif K. (2004), Effect of moisture and packaging on the shelf life of wheat flour. International Journal of Food Safety, 4, pp. 1-6.

13. Ekanem A.M., Osuji J.O. (2006), Mitotic index studies on edible cocoyams (Xanthosoma spp and Colocasia spp), African Journal of Biotechnology, 5(10), pp. 846-849.

14. Ekwe K., Nwosu K., Ekwe C., Nwachukwu L. (2009), Examining the underexploited values of cocoyam (Colocasia and Xanthosoma spp.) for enhanced household food security, nutrition and economy in Nigeria, Proceedings of the International symposium on underutilized plants for food security, income and sustainable development, Acta Horticulture, 86, pp. 71-78.

15. Food and Agricultural organization (FAO) (2006), Faostat, statistical division of the food and collections. Subset agriculture. Agricultural organization.

16. Godon M. N. (2000), Contemporary nutrition issues and insights. $4^{\text {th }}$ Ed. Mc-Graw Hill companies, New York, pp. 102-256. 
17. Hassan G. F., Yusuf L., Adebolu T.T., Onifade A. K. (2015), Effect of fermentation on mineral and anti-nutritional composition of cocoyam (Colocasia Esculenta), Sky Journal of Food Science, 4(4), pp. 042-049

18. Idowu M. A., Adeola A.A. (2017), Quality Evaluation of cocoyam-cowpea flour blends and sensory attributes of their cooked paste (amala), Annals. Food Science and Technology.

19. Ihekoronye, A.I., Ngoddy, P.O. (1985), Integrated Food Science and Technology for the Tropics, Macmillan Publisher, London.

20. International Institute of Tropical Agriculture, (IITA), (2008), Text of a speech presented by the International Institute of Tropical Agriculture (IITA) at the 1st International Workshop on cocoyam, IRAD, Ekonna, Cameroon, October 29-31, 2008.

21. Iwe M.O. (2002), Handbook of Sensory Methods and Analysis. Rojoint Communications Services Ltd, Uwani - Enugu Nigeria.

22. Jane, J., Shen, L., Lim, S., Kasemsuwantt, T. and Nip, W.K. (1992), Physical and chemical studies of taro starches and flours, Cereal Chemistry, 69, pp. $528-535$.

23. Karim O. R., Kayode R.M.O., Oyeyinka S. A., Oyeyinka A. T. (2015), Physicochemical properties of stiff dough "amala" prepared from Plantain (musa paradisca) flour and moringa (moringa oleifera) leaf Powder. Food Science and Quality Management, 4(1), pp. 48-58.

24. Key A.J. (1987), Some factors influencing the protein content of root crops. Papua New Guinea Crops Conference, Department of Agriculture, Port Moresby, pp. 6374.

25. Lawal O.O., Agiang M.A., Eteng M.U (2012), Proximate and anti-nutrient composition of white Guinea yam (Dioscorea rotundata) diets consumed in Ibarapa, South West region of Nigeria. Scholars Research Library, Journal of National plant Resources, 2(2), pp. 256-260.

26. Morris A.A., Barnett, B. (2004), Effects of processing on nutrient content of foods. Cajarticles, 37, pp. 160-164.

27. Novozamsky I., Houba V.J.G., Van E.C.K., Van V.W. (1983), Plant nitrogen and phosphorus in plant tissue, novel digestion technique for multi-element, Plant Analysis Community Soil Science Plant Analysis, 14, pp. 239-248.

28. Obadina A., Babatunde B.O., Ifeoluwa O. (2014), Changes in nutritional composition, functional and sensory properties of yam flour as a result of presoaking, Food Science and Nutrition, 2, pp. 6, 676-681.

29. Obadina A, Ashimolowo H, Ifeoluwa O. (2016), pp. Quality changes in cocoyam flours during storage, Food Science \& Nutrition 4(6), pp. 818-827

30. Omeghein A.A., Obafemi, M.O., Oyibo, S. (1998), pp. Processing parameters for cocoyam flour production In: Proceedings. 22nd Annual Conference of Nigerian Institute of Food Science, and Technology, Oct. 12-16, Abeokuta, Nigeria, pp. 131- 152.

31. Ogunlakin G. O., Oke M. O., Babarinde G. O., Olatunbosun D. G. (2012), Effect of drying methods on proximate composition and physicochemical properties of cocoyam flour. American, Journal of Food Technology, 7, pp. 245-250

32. Onayemi O., Nwigwe, N.C. (1987), Effect of processing on the oxalate content of cocoyam, Food Science and Technology, 20(6), pp. 293-295.

33. Onimawo E. A. and Asubor P. L. (2012), Food Chemistry (Integrated approach with biochemical background) $2^{\text {nd }}$ ed. Joyal printing press, Ibadan, Nigeria. 
34. Onwueme I.C. (1978), The Tropical Tuber crops, yam, cassava, sweet potato and cocoyam, John Wiley and Sons, New York and Brisbane Toronto, pp. 199-227.

35. Otegbayo B., Oguniyan D., Akinwumi O. (2013), Physicochemical and functional characterization of yam starch for potential industrial applications, Starch/Starke 65, pp. 1-16

36. Owusu-Darko P. G., Paterson A., Omenyo E. L. (2014), Cocoyam (corms and cormels), An underexploited food and feed resource, Journal of Agricultural Chemistry and Environment, 3(1), pp. 22-24.

37. Perez E.E., Gutierrez M.E., De Delahaye E.P., Tovar J,. Lares M. (2007), Production and characterization of Xanthosoma sagittifolium and Colocasia esculenta flours, Journal of Food Science, 72, pp. 367-372.

38. Savage, G.P., Dutta, P.C. and Rodriguez-Estrada, M.T. (2002), Cholesterol oxides: Their occurrence and methods to prevent their generation in foods, Asian Practical Journal Nutrition, 11, pp. 72-78

39. Sefa-Dedeh S. Agrir-Sackey, E.K. (2004), Chemical composition and the effect of processing of oxalate content of cocoyam Xanthosoma sagitifolium and Colocasia Esculenta cormels, Food Chemistry, 85 (4), pp. 479-487.

40. Temesgen M., Retta, N. (2015), Nutritional potential, health and food security benefits of taro (Coloscasia escluenta), A review, Food Science Quality Management, 36, pp. 23-30.

41. Thompson J., Manore M. (2005), Nutrition: An applied approach, Pearson Education, Inc., San Francisco.

42. Wiriya P., Paiboon, T., Somchart S. (2009), Effect of drying air temperature and chemical pretreatments on quality of dried chilli, International Food Research Journal 16, pp. $4-7$. 